\title{
Tamgalytas and Kaishy are Lamaist cult sites of in Zhetusy
}

\author{
DOI: $10.31551 / 2410-2725-2018-4-3-394-411$
}

\section{Grigoriev Fedor Pavlovich}

Head of the archaeology collection of the register of monuments NIPP of RSE «Kazrestavratsiya». Republic of Kazakhstan, 050002, Almaty, Gogol str., 37. E-mail: restavracia@mail.ru.

\section{Ualtayeva Altyn Slamkaydarovna}

Candidate of historical sciences, the Associated Professor, Leading scientific Employee of the Ch. Valikhanov Institute of History and Ethnology. E-mail: altyn.lazzat@mail.ru

\section{Zheleznyakov Boris Anatolevich}

Doctoral candidate PhD of the al-Farabi State University, Senior scientific Employee of the A. Margulan Institute of Archaeology. E-mail: boriszheleznyakov@mail.ru

\begin{abstract}
Article is devoted to history of researching of the unique site of Buddhist culture known in science more than one and a half centuries - Tamgalytas, situated in Talgar district of Almaty region. Images of Lamaist deities and the cut numerous Tibetian and Dzungarian pray inscriptions on fragments of rocks of the natural boundary Tamgalytas are scientifically described. The analysis of both national and foreign historiographical material in which this site of the Buddhism was investigated is made. Conclusions on structure, an iconography and art style of images of language, calligraphy, technology of execution and maintenance of inscriptions are drawn on the basis of what the prospects of further studying of history and several stages of formation of the sanctuary Tamgalytas are designated. Also the brief description of the site of Kaishy in Zhetusy Alatau Mountains gives.
\end{abstract}

Keywords: Tamgalytas; Kaishy; Buddhist culture; Tibet and Dzungarian pray inscriptions; Manla Buddha.

Тамғалытас және Қайша - Жетісудағы ламаистік табынудың ескерткіштері

\section{Григорьев Федор Павлович}

«Қазқайтажаңарту» ЖЖҚ ҒЗМ ескерткіш бөлімі археология секторының меңгерушісі. Қазақстан Республикасы, 050002, Алматы қ, Гоголь к, 37. E-mail: restavracia@mail.ru.

\section{Уалтаева Алтын Слямкайдаровна}

тарих ғылымдарының кандидаты, ҚР БҒМ ҒК Ш.Уәлиханов атындағы тарих және этнология Институтының жетекші ғылыми қызметкері. Қазақстан Республикасы, 480021, Алматы қ, Шевченко, 28. E-mail: ualtayeva_altyn@mail.ru.

\section{Железняков Борис Анатольевич}

Әл-Фараби атындағы қазақ ұлттық университетінің докторанты, ҚР БҒМ ҒК Ә.Х. .Марғұлан атындағы тарих және этнология Институтының аға ғылыми қызметкері. Астана қ. Қазақстан Республикасы, 010000, Астана қ, Республика д, 24. E-mail: boriszheleznyakov@mail.ru

Аңдатпа. Бұл мақалада ғылымның көп жылдық тарихы бар, Будда мәдениетінің бірегей ескерткішінің тарихына арналған, ол ғылымдарда 500-ден астам ғасырлар бойы белгілі - Алматы облысының Талғар ауданында орналасқан Тамғалытас. Тамғалытас үзінділерде ламаисттік құдайлардың ғылыми суреттемелері бейнеленген және көптеген Тибет-Жоңғар дұға жазулары жазылған. Буддизмнің осы ескерткіші зерттелген отандық және шетелдік тарихи материалға талдау жасалды. Қорытындылар тілдік бейнелер, иконографиясы және көркемдік стилі, жазулардың мазмұны, оның негізінде тарихты әрі қарай зерделеу перспективалары және Тамғаласу ғибадатханасының қалыптасуының бірнеше кезеңдері көрсетіледі. Сондай-ақ Жетісу Алатауындағы Қаишаға арналған ескерткіштің қысқаша сипаттамасы берілген.

Түйін сөздер: Тамғалытас; Қаиша; Будда мәдениеті; Тибет-Жоңғар дұға жазулары; Манла будда. 


\section{Тамгалытас и Кайши - памятники ламаистского культа в Жетысу}

\section{Григорьев Федор Павлович}

заведующий сектором археологии Отдела Свода памятников НИПФ РГП «Казреставрация». Республика Казахстан, 050002, г. Алматы, Гоголя, 37. E-mail: restavracia@mail.ru.

\section{Уалтаева Алтын Слямкайдаровна}

кандидат исторических наук, ведущий научный сотрудник Института истории и этнологии имени Ч.Ч. Валиханова КН МОН РК. Республика Казахстан, 480021, г. Алматы, Шевченко, 28. E-mail: ualtayeva_altyn@mail.ru.

\section{Железняков Борис Анатольевич}

докторант Казахского национального университета имени аль-Фараби, старший научный сотрудник филиала Института археологии имени А.Х. Маргулана КН МОН РК в г.Астана. Республика Казахстан, 010000, г.Астана, пр.Республики, 24. E-mail: boriszheleznyakov@mail.ru

Астракт. Статья посвящена истории уникального памятника буддийской культуры, имеющего длительную историю изучения, известного в науке уже более полутора столетий - Тамгалытас, находящегося в Талгарском районе Алматинской области. Научно описаны изображения ламаистских божеств и высеченных многочисленных тибето-джунгарских молитвенных надписей на обломках скал урочища Тамгалытас. Сделан анализ как отечественного, так и зарубежного историографического материала, в котором исследовался этот памятник буддизма. Сделаны выводы по составу, иконографии и художественному стилю изображений языка, каллиграфии, техники исполнения и содержания надписей, на основе чего обозначены перспективы дальнейшего изучения истории и нескольких этапах формирования святилища Тамгалытас. Дается и краткое описание памятника Кайши в Жетысуйском Алатау.

Ключевые слова: Тамгалытас; Кайши; буддийская культура; тибето-джунгарские молитвенные надписи; Манла Будда.

Удк 94(100)"05

\section{Тамгалытас и Кайши - памятники ламаистского культа в Жетысу}

\section{Ф.П. Григорьев, А.С. Уалтаева, Б.А. Железняков}

Введение. Важное место в современном научном осмыслении исторического процесса занимают региональные исследования. Примером этому служит изучение уникального памятника буддийской культуры - Тамгалытас.

В 25 км северо-западнее г. Капчагая, на правом берегу р. Или находится урочище Тамгалытас (Талгарский район Алматинской области). На прибрежных обломках скал урочища изображены ламаистские божества и высечены многочисленные тибето-джунгарские молитвенные надписи. Тамгалытас - уникальный памятник буддийской культуры, имеет длительную историю изучения и известен в науке уже более полутора столетий. Первым исследовал и сделал зарисовки буддийских изображений и надписей в урочище Тамгалытас, который в его работах также называется Тамгалыяр, Ч. Ч. Валиханов в 1856 г. (Валиханов 1984: 350).

Весной 1857 г. здесь побывал вместе с художником из Томска П. Кошаровым географ П.П. Семенов-Тян-Шанский (Семенов Тян-Шанский 1946).

Ha IV археологическом съезде России в г. Казани в 1877 г. было сделано сообщение о древностях Верненского уезда, в том числе Ларионовым о буддийском памятнике Тамгалы-Таш на берегу р. Или (Казань, 1884.). На съезде была продемонстрирована археологическая карта Семиреченского края (Вер- 
ненский, Капальский и Иссык-кульский уезды) с приложением кратких описаний, фотографий и рисунков известных к тому времени памятников древности.

В 1884 г. камень с тремя буддийскими божествами осмотрел хранитель 3оологического музея Петербургского университета А.М. Никольский, проплывший на лодке от Илийского выселка до оз. Балхаша: «верстах в 30 от выселка Илийского на прибрежной отвесной скале начертано огромное изображение человека, видимо китайской работы» (Никольский 1885: 53). Затем упоминания - Тамгалытасе встречаются у многих исследователей, изучавших прошлое Семиреченского края и долину р. Или.

Краткая справка о Тамгалытасе имеется в сводном труде И.А. Кастанье, изданном в 1910 г. В нем перечисляются и другие местонахождения буддийских изображений и надписей, найденных в Семиречье на рубеже XIX-XX вв. Например, «калмыкские рисунки и надписи» Югень-Тас, на горном перевале между Капалом и Жаркентом, недалеко от Каракола, тибетские и монгольские надписи на р. Кегень (Кастанье 2007: 384).

Тема изучения буддизма в Жетысу и Центральной Азии в целом остается актуальной, вызывающей острые споры среди ученых. В качестве примера можно привести конструктивную критику Б.А. Литвинским (Литвински 2001: 1881990) и Г.А. Кошеленко (Кошеленко 2001: 200-210) множества отдельных недостатков монографии Б.Я. Ставиского. Не вдаваясь в подробности этой критики, отметим лишь, что многие важнейшие вопросы путей распространения буддизма в период, начиная с античности до нового времени остаются остро дискуссионными. Так, на раннем этапе Центральная Азия служила своеобразным мостом - «ретранслятором» распространения этой религии из Южной Азии в Восточную. Лишь относительно короткое время на юге региона существовало преимущественно буддийское Кушанское государство. В то же время известны сообщения письменных источников о ранних парфянских проповедниках буддизма в Китае - Ань Ши-гао и его ученике Ань Сюане, относящиеся ко ІІ в н.э. (Литвинский 1992: 442-443), а также о паломничестве в Индию Сюань-Цзяня в 7 в., оставившего записки о маршруте своего путешествия, включая Таласскую долину и Южный Казахстан (Зуев 1960: 87-96).

Материалы и методы. В современной отечественной истории и историографии накоплен существенный исследовательский опыт, позволяющий подвести некоторые итоги и определить возможные перспективы движения вперед исторического сообщества по пути дальнейшего изучения древней и средневековой истории. Открытие архивных фондов, рассекречивание многих архивных документов, публикация новых тематических документальных и статистических сборников, переиздание уникальных монографических изданий прошлых лет принципиально расширили источниковую базу исторических исследований, стимулировали рост интереса исследователей, как к традиционным, так и к новым темам и сюжетам.

Обсуждение. Но наиболее инфрормативным и по описанию, переводам и интерпретации буддийских изображений и надписей Тамгалытас были и до сих пор остаются работы Н.Н. Пантусова и А.М. Позднеева.

В сентябре 1897 г. Н.Н. Пантусов совершил поездку на р. Или, чтобы специально ознакомиться с буддийскими изображениями, дал общее описание святилища, определил количество камней с божествами и надписями, сделал их полную фотофриксацию.

Н.Н. Пантусов установил, что в урочище Тамгалытас надписи и изображения бурханов сделаны на камнях, обрушившихся с высокого скалистого берега. 
«На самом большом из этих камней высечены три изображения бурханов и с правой стороны внизу сделаны надписи». Ниже влево от этого камня и затем далее правее «есть еще два отдельных камня с одноличными изображениями бурханов. Над головой левого бурхана изображено семь змей... Всего, таким образом, изображений бурханов найдено здесь пять: три на одном камне и два других на камнях, из последних двух один (лежащий левее большого бурхана) не имеет надписей... Кроме камней с изображением бурханов, есть еще на семи отдельных камнях крупные и мелкие калмыцкие и тибетские надписи...» (Пантусов 1898: 273-276).

Востоковед А.М. Позднеев по снимкам Пантусова надписи перевел, идентифицировал изображенные на камнях буддийские божества, снабдив объяснения подробными комментариями. Его исследование, выполненное на высоком научном уровне, не потеряло своей значимости до сих пор, но к сожалению, забыто многими современными исследователями, занимающимися изучением этого памятника буддийской культуры (Позднеев 1898: 275-282).

В советский период Тамгалытас надолго выпал из поля зрения исследователей, став прибежищем самодеятельных туристов и путешественников. Интерес к нему вновь поднимается в 60-е годы прошлого столетия, что было связано с изданием полного собрания трудов Ч.Ч. Валиханова. С этого времени Тамгалытас неоднократно осматривался различными специалистами - искусствоведами, археологами, историками, географами и др. Надписи и изображения Тамгалытас были проанализированы А.X. Маргуланом. Он высказал предположение о джунгарском происхождении композиции, а создание комплекса датировал XVII-XVII вв. (Маргулан 1972: 23).

В 1970 г. издана книга Н. Нурмухаммедова о памятниках искусства Казахстана, где были помещены фотографии камня с «тремя буддами» и высказаны предположения о их датировке и историко-культурной принадлежности. В феврале 1981 г. Тамгалытас был взят на госохрану как памятник местного значения. Летом 1981 г. буддийский памятник обследовал археолог института «Казпроектреставрация» Ф.П. Григорьев, сделавший фотофиксацию центральных изображений и надписей.

Но наиболее интенсивно Тамгалытас изучается в последнее десятилетие. Памятник привлек внимание зарубежных специалистов по буддизму П.Стобдана и Ж.М. Деома, давших свое понимание и толкование божеств и надписей этого ламаистского комплекса (Стобдан 2000).

В 2006 г. вышла книга А.Н. Марьяшева и С.А. Потапова об археологических памятниках правобережья р. Или, предназначенная «для широкого круга читателей... и подготовки экскурсий» (Марьяшев, Потапов 2006: 16-19). Есть в ней раздел, посвященный святилищу Тамгалытас. К сожалению, информация о памятнике запутана, содержит много неточностей, ошибки в определении персон и функций, изображенных божеств, малоубедительные выводы, что стало результатом недостаточной проработки автором раздела по историографии Тамгалытаса и буддизму (ламаизму) в целом.

В 2008 г. исследования святилища провела группа специалистов НИПФ РГКП «Казреставрация» (Искаков, Каппасов) с целью подготовки проекта по благоустройству территории памятника. Ими были закартографированы, описаны и сфотографрированы буддийские изображения и надписи на 10 камнях (плоскостях) в центральной части урочища. В том же году фоотофиксацию и копирование надписей, чтение которых вызывало вопросы у специалистов, сделала экспедиция КазНИИ ПКНН (А.Е. Рогожинский) (Ерофреева 2009: 43). 
Результаты. Все исследователи Тамгалытаса основное внимание уделяли большому обломку скалы, на гладкой плоскости которого выгравированы три сидящих на лотосах бурхана. Этот камень с божествами обладает наибольшей атрактивностью, вероятно, является центральной частью святилища. В центре камня находится величественный по размерам (3,46×3,79 м), атрибутам и манере изображения бурхан, слева и справа от него - более мелкие фиигуры божеств.

По определению А.М. Позднеева, величественный бурхан в центре камня именуется у монголов и джунгаров Ария (Арья)-бало (тиб. Чжан-рай-сик, Ченраиси). В буддизме Махаяны - это бодхисатва Авалокитешвара, ставший одним из самых популярных божеств в ламаистском пантеоне, олицетворяющий сострадание. Он изображен в виде индийского принца с 13-ю украшениями, сидящего в «алмазной» позе. Передняя пара рук божества сложена для молитвы. В правой задней руке он держит хрустальные четки, а в левой - цветок лотоса с длинным стеблем. Такая фрорма изображения Авалокитешвары сложилась в позднейшем тантрическом периоде и наиболее распространена в ламаизме. Ламаисты считают Авалокитешвару эманацией дхьяни - будды Амитабы, а его земным воплощением далай-ламу. Под изображением Авалокитешвары тибетская надпись: «Поклоняюсь святому Чжан-рай-сику» (Позднеев 1898: 276-282). Справа от Авалокитешвары (Чжан-рай-сик'а) в меньших размерах $(1,42 \times 1,44$ м) расположен Будда Шакъямуни с чашей для подаяния в левой руке. Под ним надпись на тибетском языке: «Поклоняюсь Будде Шакьямуни». Слева от Чжан-рай-сик'а выгравирован Манла Будда (Будда исцеляющий) размерами 1,79×1,46 м. В левой руке он держит закрытую на замок патру, а в опущенной вниз правой - исцеляющий все болезни плод (золотой миробалан). Под фригурой Манлы тибетская надпись: «Поклоняюсь Будде Манла».

Четвертый одиночный бурхан $(1,28 \times 1 \mathrm{~m})$ с семью змеями над головой выбит на камне без надписей в 15 м к западу от центральной композиции с тремя божествами. Это «Лу-ван» - особое божество, изображавшееся отдельно и почитаемое ламаистами как хранитель освящаемого им места. В монгольских мифах Лу-ван - «могущественный хан драконов». Над его головой изображаются в разном количестве «драгоценные» змеи. В Тамгалытасе Лу-ван изображен с руками в положении проповеди. Он является спасителем драконов и подобных им существ. Лу (лусы, лусуты), как правило, духи и хозяева водоемов, а в бурятской мифологии - исключительно водоемов. По представлениям калмыков, «черные лусы» - это вообще духи природы. В преданиях монгольских народов первый лусут Луван Луин Джамбо (от тиб. Лу Ван Лу Жалбо, санскр. Нагешвара раджа - «государь - владыка змей»), вылупившийся из змеиного яйца в виде дракона (Лу), был возведен богами в ранг управляющего всеми водами на земле и ханом 77 царств лусутов, которые, родившись от него, заселили все озера, ручьи, колодцы и другие водоемы (Мифологический словарь 1991: 73, 321-323).

Еще один, сидящий на лотосе одиночный бурхан (пятый) размерами $1,27 \times 1,4$ м изображен на камне в 26,5 м к ЮЮЗ от центральной композиции святилища. В тибетском ламаизме он именуется Митюкба («невозмутимый»). В буддизме это божество принадлежит к числу пяти дхьяни-будд и называется Акшобхья. Акшобхья - хранитель Востока. Отличительным признаком этого божества является ваджра на левой ладони. Ваджра в виде топора, трезубца, палицы, фраллоса, алмаза, молнии - важный инструмент в ритуалах тантризма, символизирует мужское начало, путь, активность, прочность и неуничтожимость в буддизме. Справа от изображения Акшобхьи- надписи на тибетском языке, содержащие охранительные формулы и молитвенные заклинания (тар- 
ни) Митюкбе, а над ними и под ними калмыцкими и тибетскими буквами начертано четыре раза «Ом ма ни пад ме хум».

Итак, в Тамгалытас изображены следующие божества буддийсколамаистского пантеона: Будда (Гаутама Шакьямуни), дхьяни-будда Акшобхья (тиб. Митюкба), Будда Манла, дхьяни-бодхисатва Авалокитешвара (тиб. Чжанрай-сик, монг. Ария-Бало), Будда Лу-ван.

На отдельных камнях святилища и под божествами выбито около пятидесяти надписей на тибетском и монгольском (ойратском) языках. По количеству надписей с Тамгалытасом можно сравнить святилище в ущелье Тайгак в горах Шолактау, где по данным одних исследователей известно 50 тибетских и 1 монгольская надпись, представляющих буддийское заклинание «Ом-манипадме-хум», а по сведениям других - всего 27 молитвенных надписей на тибетском языке, но там отсутствуют изображения божеств.

Половина надписей в святилище Тамгалытас также является сокращенным или полным вариантом молитвенного заклинания «Ом-мани-падме-хум» - символа веры и молитвы ламаистов. Постоянное повторение, а по-возможности и начертание этой магической мантры, по их мнению, приближает верующего к достижению небесного просветления. Существует немало версий, поясняющих смысл и ритуальное значение этой мантры (Марьяшев 1998: 15).

Наиболее обоснованной, на сегодняшний день, является точка зрения Н.Л. Жуковской, обратившей внимание на скрытый смысл слов «мани» (идентично «ваджре») и «падме», как символов мужского и женского начал в их единении (слиянии), восходящих к раннему тантризму и земледельческим культам Индии. Реликт этого в тибетском, монгольском и бурятском ламаизме - магическая мантра ом мани падме хум (Жуковская 1977: 66-68).

В определенном смысле «едва ли не вся специфика ламаизма, многие его культы и обряды возникли в первую очередь на основе буддийского тантризма» (Васильев 1983: 347).

В ваджраяне это заклинание является мантрой бодхисатвы Авалокитешвары и пишется в виде шестичленной фрормулы ом ма ни пад ме хум и. На уровне йоги в практике созерцания слоги ма, ни, пад, ме, хум служат символом коголибо из пяти дхьяни-будд, а самый первый слог ом - символ Авалокитешвары.

П. Стобдан дает иное объяснение этой формулы. По его словам, простое произнесение этой мантры «может остановить цикл нового рождения в шести мирских реальностях, таких как $\mathrm{Om}$ - боги, Ma - титаны, $\mathrm{Ni}$ - человек, $\mathrm{Pad}$ зверь, Ме - Тантал и Нum - житель ада» (Стобдан 2000: 185).

Из других надписей святилища Тамгалытас пять содержат обращение к Митюкбе (Акшобхье), по две надписи - к Буддам Манла и Шакьямуни.

Встречаются также тарни бодхисатвы Манджушри, который в ваджраяне (особенно в Тибете) с Авалокитешварой и Ваджрапани относится к числу трех главных бодхисатв. Это божество принадлежит к семье Акшобхьи и почитается в ламаизме наряду с Буддой Шакьямуни, Адибуддой, дьхяни-буддой Амитабой, бодхисатвой Авалокитешварой и буддой грядущего Майтрейей. Манджушри (Маньчжушри) олицетворял и считался покровителем мудрости, носителем божественного откровения и чуть ли не устроителем Вселенной. Культ Манджушри был особенно популярным в Тибете и Китае, его земным воплощением считался Цзонкава - основатель школы гелукпа в нач. XV в. (Мифологический словарь 1991: 340).

На одном камне, где высечены 10 молитвенных строк на калмыцком языке содержится надпись на тибетском: «поклоняюсь Чойчжи-чжалцану» - реальной исторической личности XVII в. Эта надпись очень важна, на наш взгляд, для 
определения датировки памятника, которая долгое время оставалась наиболее сложным вопросом в его изучении. Если надписи Тамгалытаса, выбитые монгольским шрифтом, рассматривались многими исследователями как оставленные калмыками в период джунгарского нашествия XVII-XVIII вв., то датировка изображений на большом камне святилища и тибетских надписей безосновательно удревнялась. Например, Н. Нурмухаммедов изображения трех будд на большом камне относил ко II в. н.э. и связывал их с сакскими племенами, вернувшимися в Жетысу из Северной и Западной Индии (Нурмухаммедов 1970: 15-16, 35-36). По мнению Н.П. Шастиной, каллиграфия тибетских надписей Тамгалытаса свидетельствовала о датировке их не ранее VII в., а надписей, высеченных на калмыцком языке, - после XII в. Сходного мнения придерживался П. Стобдан, по которому илийские изображения и надписи принадлежали к более раннему периоду, чем X или XI вв.

Версия о раннем происхождении буддийских петроглифов (рубеж н.э. и раннее средневековье) вызывала сомнения у специалистов из-за особенностей палеографии надписей и иконографии выбитых божеств. Было высказано также предположение, что изображения могли быть оставлены в X-XVI вв. уйгурами, монголами, калмыками или киргизами, исповедовавшими буддизм в этот период. Поднимался также вопрос о возможности возникновения святилища в период каракиданьского (карахытайского) проникновения в регион в XII-XIII вв. и др.

Археологические исследования в Северной Киргизии выявили, что в городской культуре Жетысу появление буддийских памятников происходит в VII-IX вв., в период связей Тюркских каганатов с Восточным Туркестаном и Китаем (Горячев 2007:132). В развитом и позднем средневековье в Центральную Азию устремился новый поток носителей буддийской культуры. B VII-IX и XII-XIII вB. буддийская культура в Жетысу поддерживалась за счет проповеди паломников-буддистов из Китая, затем Монголии и Маньчжурии, но, главным образом, за счет миграции населения из перечисленных регионов в западном направлении. Несмотря на то, что в VII-XIII вв. буддизм в Жетысу распространялся с востока, Ж.М. Деомом выделены периоды распространения буддизма в обратном направлении с запада на восток, в частности, в Китай в период Тюргешского каганата (704-754) и уйгурской империи (840-1240).

Таким образом, народы Восточного Туркестана в течение длительного времени являлись носителями и «экспортерами» буддийской культуры как на запад, так и на восток. В Жетысу после IX-X вв. буддизм приносился паломниками и мигрантами с востока. Одним из длительных периодов распространения здесь этой религии был период джунгарского нашествия.

В ламаизме далай-лама считается воплощением Авалокитешвары, а панчен-лама - воплощением будды Амитабы. И хотя воплощение будды в сакральном плане выше воплощения бодхисатвы, в Тибете именно далай-лама сосредоточил в своих руках высшую духовную и политическую власть, и стал общепризнанным верховным авторитетом для всех ламаистов и многих буддистов за пределами сфреры распространения этого учения.

Проанализировав состав, иконографию и художественный стиль изображений язык, каллиграфию, технику исполнения и содержание надписей можно высказать предположение о нескольких этапах формирования святилища Тамгалытас. К начальному этапу, вероятно, относится установка камня с Лу-ваном, чье изображение более простое по исполнению и не имеет надписей. Известно, что именно в XVII-XIX вB. в местах распространения северного варианта буддизма - ламаизма, в Сибири и Забайкалье появляются новые памятники с 
изображениями буддийских божеств, например, Лубан Жалбо Бурхана, владыки вод, озер, рек. Бурхан - тюрко-монгольская модификация слова «Будда» или словосочетания «Будда - хан», в шаманской мифологии монгольских народов, применяется обычно к не смешиваемым с Тенгри индо-тибетским ламаистским божествам. Поскольку предшественником буддизма в Тибете была местная религия бон (бон-по) с ее, преимущественно анимистическим культом божеств, духов и сил природы, то сложившийся на этом культурном фроне ламаизм многое впитал в себя из нее и основан на шаманской практике тибетцев и монголов (Токарев 1976: 346). Поэтому в XVII-XIX вв. широко распространяется ламаистская традиция устанавливать стелы с надписями и благопожеланиями по случаю преодоления реки, трудного участка дороги или перевала.

Полноводная и стремительная Или, безусловно, служила значительным препятствием на пути. В середине XIX в. через нее были три переправы, о чем указывал Ч.Ч. Валиханов: «Весенний разлив Или бывает не ранее марта месяца; осенью же она так мельчает, что в сентябре и октябре образуются броды, удобные для прохода скота, так, известны три брода: Огуз-откель, между устьями Чилика и Тургена; Кыз-кечу, или Кыз-уткель, между Иссыком и Талгаром, немного ниже впадения с правой стороны р. Чингильды и Тамгалы-уткель, при урочище Тамгалы-тас. Через последний идет караванный путь из Ташкента в Кульджу и на Семипалатинск и называется Джанайджол (Джанаевский путь)» (Валиханов 1984: 174). Второй брод был известен тем, что через него в 1701 г. переправилась часть бежавших с Волги в Джунгарию калмыков (торгоутов). Напротив этой записи на полях рукописи Валиханова пометка: «Ниже есть еще брод Уч-арал».

В 1898 г. урочище Тамгалытас по просьбе Ф.В. Пояркова осмотрели учитель Илийского выселка В.Т. Толмачев и хорунжий Семиреченского казачьего полка Н.С. Сазонтов. Они сообщили, что существующий около Тамгалытаса брод образовался от каменного порога, по которому можно перебраться верхом на лошади на другую сторону реки. Среди местных казахов держится мнение, что высеченные здесь фригуры и надписи - китайские. Они рассказали, что «около Тамгалытаса зарыто большое богатство и невдалеке от этого места будто бы был устроен через реку Или китайский мост, который мог опускаться и подниматься «на винтах». Казахи этим бродом теперь не пользуются, но «один из кульджинских правителей, будучи в этих местах и прочитавши надписи на Тамгалы-тасе ... переезжал реку Или в брод по упомянутому порогу. Очевидцы этого фракта, как утверждают киргизы [казахи - авт.], живы и теперь...». (Поярков 1898: 59-60). Эти сведения, на наш взгляд, говорят о том, что переправа в урочище Тамгалытас была наиболее оживленной в джунгарский период. Скопление буддийских божеств и надписей около нее свидетельствует о том, что местность в этот период активно посещалась верующими ламаистами.

Основной этап формирования святилища Тамгалы - создание центральной высокохудожественной композиции с тремя бурханами. Этот этап, связан с появлением в урочище лам-проповедников из Тибета. Ими был выбран огромный, лучший по экспозиции, с гладкой поверхностью обломок скалы, на котором были выгравированы изображения Чжан-рай-сика, будд Шакьямуни и Манла, и нанесены надписи - молитвы на тибетском языке. Все рисунки и надписи были сделаны с высоким профессионализмом, как заметил П. Стобдан - «работа художников». Изображения отличают четкость, изящество и тонкость гравировки. 
Уточнить хронология этого этапа, на наш взгляд помогает переведенная А. Позднеевым уже упоминавшаяся надпись на одном из камней в Тамгалытасе, сделанная таким же шрифтом: «поклоняюсь Чойчжи-чжалцану». Как известно, Чойчжи-чжалцан (1569-1662) жил в Тибете, имел множество религиозных званий. Он был первым ламой, носившим высокий титул Панчен-римпоче, или панчен ламы, создал Пятого Далай-ламу Агван-Лобсан Чжалицо (1617-1782) (Позднеев 1898: 282) имевшего большое влияние на Галдана хунтайджи, правившего в Джунгарии в 1671-1697 гг. Как известно, Галдан отличался повышенной религиозностью и воинственностью при распространении ламаизма. Он провел много лет в Лхасе и собирался посвятить свою жизнь Шакьямуни. Но в 1671 г., сняв с разрешения Пятого Далай ламы духовный сан служителя ламаистской церкви, провозгласили себя ханом. Все годы своего правления Галдан поддерживал тесные связи с Агван-Лобсаном и его регентом Дэсрид Санчжай Чжалицо (1653-1705) (Моисеев 1991: 49, 52).

Мы полагаем, что создание центральной части святилища Тамгалытас было совершено в правление Галдана. Именно при нем Семиречье было закреплено за джунгарами, а ставка хана и основные кочевья были перенесены с Иртыша в бассейн р. Или. Вероятно, в этот период по просьбе джунгаров из Тибета в Илийскую долину прибыла буддийская миссия, деятельность которой приходится на 70-80-е гг. XVII в., и Тамгалытас становится одним из ламаистских духовных объектов «освящавших» важную для джунгар переправу через труднопреодолимую реку.

Немного позднее композиции с тремя бурханами, судя по иконографии и каллиграфии надписей, было выбито на отдельном камне изображение Митюкбы (Акшобхьи) и посвященные ему тарни (Потапов 1946: 16, 17).

В дальнейшем на камнях святилища странствующими монахами или паломниками оставлялись другие надписи - мантры тому или иному божеству. По свидетельству английской путешественницы А. Марстон, побывавшей в конце XIX в. в Тибете «некоторые богатые и ревностные тибетские буддисты содержат артели лам-скульпторов, обязанность которых состоит в том, чтобы, странствуя с резцом в руках по городам, долам и пустыням, всюду вырезать священное «mani» на камнях и скалах» (Марстон 1896).

Не исключено, что этот обычай среди последователей ламаизма сложился намного раньше указанного времени и применялся вместе с распространением этой религии.

Надписи, выполненные в святилище Тамгалытас на тибетском языке и калмыцким алфавитом, отражают культурную ситуацию в Джунгарском государстве, где для религиозного образования населения широко привлекались тибетские ламы.

Известно, что буддизм в виде ламаизма распространился в Восточной Монголии и Джунгарском ханстве в начале XVII в. Около 1610 г. лама Нейджитойн отправился в кочевья ойратов. Он обратился к правителю и князьям одного из племен с предложением принять учение ламаизма, вслед за этим последовало налаживание постоянных контактов с иерархами ламаизма.

В 20-X гг. XVII в. владетельные князья Западной Монголии приняли буддизм в ламаистской форме как официальную религию, отказавшись от шаманизма (Княжецкая 1989: 19). Огромную роль в распространении и пропаганде этой религии среди ойратов и калмыков сыграл знаменитый ойратский проповедник Зая-Пандит, который в 1648 г. на основе общемонгольского алфавита создал ойратскую письменность, положив тем самым начало калмыцкой (ойратской) письменной литературе (Моисеев 2001: 335). Из этого следует, что 
первые молитвенные надписи на калмыцком языке в святилище Тамгалытас появились не ранее середины XVII в.

Учение ламаизма синтезировало на основе буддизма элементы различных древних народных верований и, главное, выдвинуло иные задачи для буддийского духовенства (лам) - не уход в отшельничество для личного спасения, а активное влияние на жизнь верующих в качестве наставников и проповедь учения. Как пишет И. Ерофеева, «...конкретным воплощением в жизнь этих идейных принципов и правил в Джунгарии стало в 40-х гг. XVII - первой половине XVIII в. повсеместное строительство буддийских храмов и монастырей. По письменным и картографическим источникам, прежде всего, карте Джунгарии, составленной пленным шведом Й.-Г. Ренатом в 1734-1738 гг., на территории современного Восточного, Юго-Восточного и Центрального Казахстана в cep. XVII - нач. XVIII в. существовало не менее 48 ойратских ламаистских монастырей (сумэ или хит). Ламаистские святилища и культовые сооружения в Джунгарии обычно располагались на открытой местности у подножия гор, возле рек или целебных минеральных источников, родников, иногда возле рудных месторождений, разрабатываемых ойратами, а также вблизи основных кочевых маршрутов и караванных путей, у речных переправ, горных перевалов и других узловых пунктов трансрегиональных коммуникаций номадов.

Таким образом, формирование и функционирование святилища Тамгалытас относится к периоду вхождения Северо-Восточного Жетысу во владения джунгар и проходило в несколько этапов. Как известно, джунгары начали вытеснять казахов из этого региона после смерти Таваккула (1598) (Абусеитова, Абылхожин, 2001: 341). После образования Джунгарского ханства (1635) и общемонгольского съезда (1640) правитель ойратов Батур хунтайджи повел уже целенаправленную политику по захвату земель казахов. В нач. 40-х годов борьба между Джунгарским и Казахским ханствами велась с переменным успехом, но ойратам удалось захватить часть Жетысу. В 50-е гг. XVII в. восточная часть Семиречья, территория между верховьями р. Иртыша и оз. Балхаш оказалась во владениях Батура хунтайджи. Его преемник хан Галдан (1671-1697) в 1672 г. перенес свою ставку (ургу) с верхнего Иртыша на правый берег р. Или, восточнее р. Хоргос и западнее г. Кульджи (Волобуев, 1993: 12 а). Но окончательно земли Северо-Восточного Жетысу были закреплены за ойратами, как считал В.В. Бартольд, в перв. пол. 80-х гт. XVII в. после походов Галдана в Южный Казахстан и Среднюю Азию, взятия городов Чимкент, Ташкент, Сайрам и др. Только на Сайрам Галдан совершил в 1681-1682 и 1684 гг. три похода, пока не разрушил его. После этого «власть калмыков в Семиречье ... никем не оспаривалась и многочисленные войны их с казахами, монголами и китайцами не имели отношения к этой области»(Бартольд 1961: 98).

По русским источникам, граница между ойратами и казахами в конце XVII в. проходила по р. Талас, Чу и горам Улытау. После гибели Галдана ставка нового джунгарского хана Цэван Рабдана (1697-1727) в 1703 г. была перенесена на левобережье р. Или, к устью р. Текес. Только в 1716 г. казахи совершили поход в кочевья ойратского племени чоросов, занимавших бассейн верхнего и среднего течения р. Или, но закрепиться там не смогли. И лишь после разгрома Джунгарского ханства в 1756-1758 гг. им удалось вернуть земли Жетысу.

Надписи с буддийским содержанием, рельефные изображения божеств буддийско-ламаистского культа, выбитые на скалах, достаточно широко распространены в Семиречье. Большинство их относится к периоду джунгарского завоевания края и выявлено до революции. Еще Ч.Ч. Валиханов 
в 1856 г. сообщил о пещере в горах от Капала на Старо-Каратальском пикете, в которой были вырыты «два медальона с изображением ламаистских богов».

В 1862 г. Н.А. Абрамовым были обследованы изображение бурхана, монгольские и джунгарские молитвенные надписи около минеральных источников Капал-Арасан (Абрамов 1867).

Изображение бурхана с надписью осмотрено Н.Н. Пантусовым в 1898 г. у пос. Карабулак, в 4 км от слияния рек Каратал, Текели и Чиже (Ескельдинский р-н Алматинской обл.) (Пантусов 1899), надписи на тибетском и монгольском языках в 1901 г. - в 46 км от с. Подгорного по дороге в Кегень.

В 1905 г. на территории г. Капала при рытье ямы был найден обломок каменной плиты с изображением бурхана (Археологическая карта Казахстана 1960: 208).

Несколько десятков буддийских монгольских надписей были обследованы Н.Н. Пантусовым в 1899 г. в ущелье Теректы в западной оконечности Джунгарского Алатау, в 6 км к ЮВ от с. Жалгызагаш. Как установили позднее археологи, надписи располагаются на кочевой тропе, ведущей из долины р. Коксу на джайляу (Марьяшев, Горячев 1998: 23, 228-232). По дореволюционным источникам в ущелье Теректы зафиксировано до 60 надписей. О большом количестве изображений буддийских божеств и надписей по берегам р. Или рассказывали в 1898 г. кочевники казахи.

В 1896 г. Н.Н. Пантусов сообщил о скоплении позднесредневековых буддийских надписей в ущелье Тайгак в горах Шолактау, в 45 км к востоку от п. Шенгельды. Обследование ущелья восемь десятилетий спустя показало, что здесь сосредоточена 51 надпись «ом-мани-падме-хум». Археологом А.Н. Марьяшевым были выявлены буддийские надписи также в ущелье Теректы в горах Шолактау, в 55 км к востоку от п. Шенгельды (Кербулакский р-н). Наскальные изображения и надписи были зафиксированы в одном из отщелков в урочище Бартогай в горах Торагыр. О буддийской кумирне у входа в Талгарское ущелье в 1929 г. сообщил И.А. Чеканский (Чеканский 1929).

Кроме того, во многих местах Северо-Восточного Семиречья ойратами были сооржены ламаистские храмы и монастыри. Современный анализ карты И. Рената, проведенный И.В. Ерофеевой показал, что из 65 обозначенных на ней культовых сооружений джунгаров («талтеров») наибольшее количество (27) располагалось на южной (левобережной) стороне р. Или - от р. Шилик до устья р. Хоргос, в бассейнах рек Темирлик, Кеген с Каркарой, Текес, Нарынкол и вокруг оз. Иссык-Куль. Талтеры находились также к северу от Или: вдоль предгорий северных склонов Джунгарского Алатау - на левобережье Каратала, Биена, Коянды, Кызылагаша, между реками Лепсы и Сарканд, 4 - вдоль югозападных склонов этого хребта и левом берегу р. Биже. На правобережье р. Или южнее хребтов Алтын Эмель и Кояндытау обозначены 2 монастыряоколо р. Тулкили и с. Коныролен (Волобуев 1993: 15 b).

По мнению 3.С. Самашева, ламаистские культовые постройки, молитвенные формулы и изображения призваны были обеспечить идеологическую поддержку джунгарским завоеваниям в казахских степях. Одним из таких памятников, по его мнению, является изображение субургана на камне в районе г. Текели (Самашев 2007: 165-186).

Заключение. Факты свидетельствуют о том, что некоторые ойратские правители действительно пытались насадить ламаизм среди казахов (Моисеев, :49-52). Например, упоминавшийся правитель джунгарского государства Галдан. По свидетельствам русских источников 1691 г., одной из причин военных походов джунгаров в казахские земли в перв. пол. 80-х гг XVII в. было стремление Галдана 
побудить владетелей и население Казахского ханства принять ламаизм. «Посылал ... Бушухту-хан [Галдан-авт.] в Казачью орду, чтобы они объединились и веровали с ним ... в одного их ламу, от того де с ними учинилась ссора, потому что они [казахи -авт.] не хотели по-калмыцки в Далай-ламу веровать и за то де у них были бои великие», - сообщали послы Галдана иркутскому воеводе. По-видимому, с этой же целью был отправлен в Лхасу - центр ламаизма один из сыновей казахского хана Тауке, взятый в пленГалданом.

Вероятно, возведение храмов и монастырей, торжественно освящаемых крупными иерархами ламаизма, как, например, Зая-Пандитом храма Аблайхит (15 км к ЮВ от с. Бозанбай, близ Усть-Каменогорска), построенном в 1655-1657 гг., преследовали эти цели. Но большинство наскальных изображений и буддийских надписей в горных районах, на наш взгляд, являлись небольшими святилищами, местными объектами религиозного культа и были связаны с своеобразным духовным освоением рядовыми кочевниками ойратами новой среды обитания и жизнеобеспечения - земель Жетысу.

Петроглифы и весь археологический комплекс Кайши расположены в месте наибольшего сужения и поднятия среднегорного плато, расположенного у южных склонов Кояндытау - юго-западного отрога Жетысуйского Алатау. Местность обильно поливается небольшими речками, вытекающими из ущелий его южных склонов, при внимательном просмотре местности заметна и система ирригации конуса выноса Кайши. В 25 км восточнее аула Коныролен. Именно этот пункт и отражен на карте Рената, где и был расположен один из ламаистских монастырей.

В нижней части конуса выноса с южных склонов Кояндытау сосредоточено более десятка курганов сакского времени разных размеров, вплоть до средних размеров царского. Выше располагаются многочисленные каменные выкладки, которые можно предварительно отнести к конструкциям святилища и жилищ, ограды, в том числе из менгиров, врытых в землю, структура которых также нуждается в документации и исследовании.

Местность пересечена многочисленными руслами речек и мореной, сползавшей с Кояндытау в ледниковый период. На валунах, оставшихся от движения морены, патинированных от солнца в эпоху бронзы и раннего железа, были выбиты многочисленные петроглифы. Число их только в центральной части $500 \times 300$ м. превышает 600. Размеры же всего памятника, растянувшегося в том числе и у подножия гор превышает размеры 2х2 км. Памятник документирован не полностью, число петроглифов превышает 1200 изображений. Имеется изображение «солнцеголового», подновленное изображение с оленями и мелкими животными с «солнцерогой» личиной. Местность связана с крупнейшим памятником региона и всего Казахстана Ешкиольмесом.

В первое посещение археологами Б.А. Железняковым, С.А. Потаповым, Л.Херманном было отмечено, что большинство изображений относятся к периоду поздней бронзы и начальному этапу раннего железного века. Видимо, природные условия того исторического периода способствовали освоению этой ландшафтной ниши именно с конца II тысячелетия и в первые века I тыс. до н.э. Дальнейшие исследования показали, что имеются и более ранние изображения.

Исходя, из результатов предварительных исследований 2011 г. по своей художественной ценности и уникальности изображений, а также составляющей ландшафта, именно Кайши значительно выделяется сравнительно с двумя другими памятниками (Сарытау, Сарыбастау), впервые опубликованными Л. Херманном, да, видимо, и сравнительно с Усеком, выделяясь масштабами (количеством петроглифов), а также значительным числом петроглифов эпохи бронзы и опре- 
деленной последовательностью в переходе к изображениям раннего железного века. С одной стороны, благодаря более широкой хронологической датировке петроглифов Кайши, где еще в эпоху бронзы были выбиты уникальные шедевры, «презентующие» воззрения той эпохи, «недосказанность» учения компенсировались высоким уровнем образности, резко изменившей облик петроглифов ближе к переходному этапу к раннему железному веку.

В последующие года была документирована плоскость на отдельной скале с выбитыми изображениями - единая композиции из двух крупных оленей и более мелких различных животных (Железняков 2017: 111-126). (Рисунок 1).

Кроме того, в местности у выхода из одного небольших ущелий со сле-

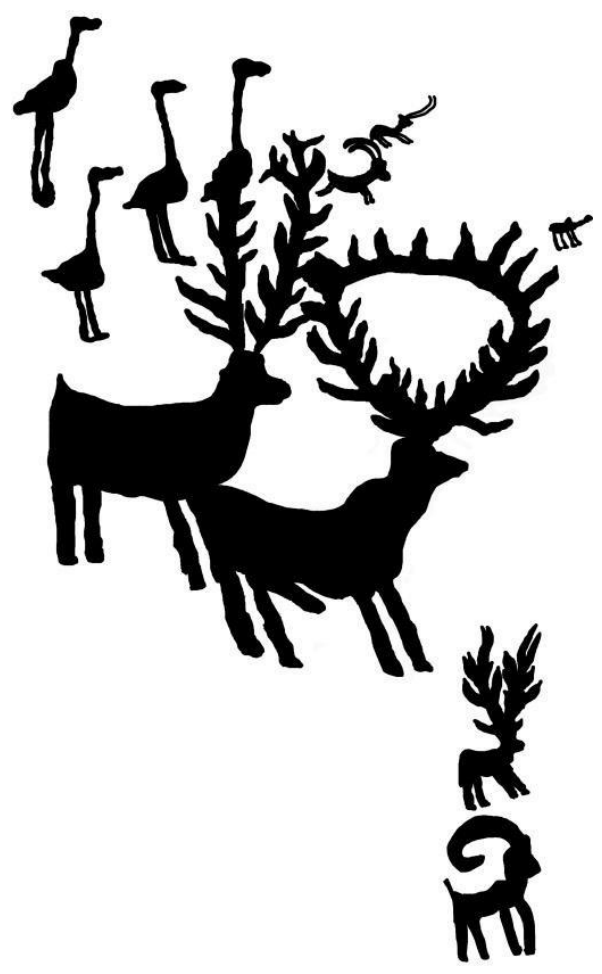

Рисунок 1. Изображение на алтарной плоскости, «солнцерогая» личина. Кайши дами ручья, ныне сухого найдены более 20 надписей на тибетском и ойратском языках: «ом-мани-падме-хум» (Рисунок 2). Также развалины 4 отдельных сооружений (одно больших размеров) (Рисунок 3) и хозяйственное сооружение в соседнем ущелье. Можно предположить, что это один из трех храмов-монастырей, построенных в 1670-х гг. на территории Джунгарии. Это было чуть позже 1648 г. когда была создана ойратская письменность («ясное письмо»). Здесь же в нескольких десятков-сотнях метров зафиксировано более 20 ойратских надписей.

Памятник изучается с 2011 г. (Hermann 201: 72). Это самое крупное скопление петроглифов из известных на настоящий момент в Южном Приджунгарьи (Жетысу Алатау). Подобные места выбирались жрецами и шаманами как языческие центры силы, где существовала незримая мировая ось. Если индийские и иранские источники об этом говорят косвенно, поскольку это уже источники других регионов, то «заставить говорить» сакральные ландшафрты горных и степных регионов Казахстана - непосредственная задача отечественных археологов и культурологов, искусствоведов. Памятник обретает новый сакральный статус (Қазақстанның киелі 2017: 140-141).

Распространенный в развитое средневековье в Жетысу и Восточном Казахстане буддизм возвратился в регион в новое время в форме ламаизма, а в новейшее - частично затронул регион в фрорме так называемого бурханизма, все больше растворяясь в народных культах и верованиях. Каждый раз носителями буддизма являлись разные этносы. В результате этого процесса религиозное учение становилось все более синкретичным, а его обряды сходными с языческими. Очевидно, что основы синкретичности буддизма были заложены в эпоху раннего средневековья с распространением у тюркских и иранских народов Центральной Азии манихейства, буддизма и несторианства, с ростом интенсивности межкультурных связей, чему посвящено множество специальных исследований. 


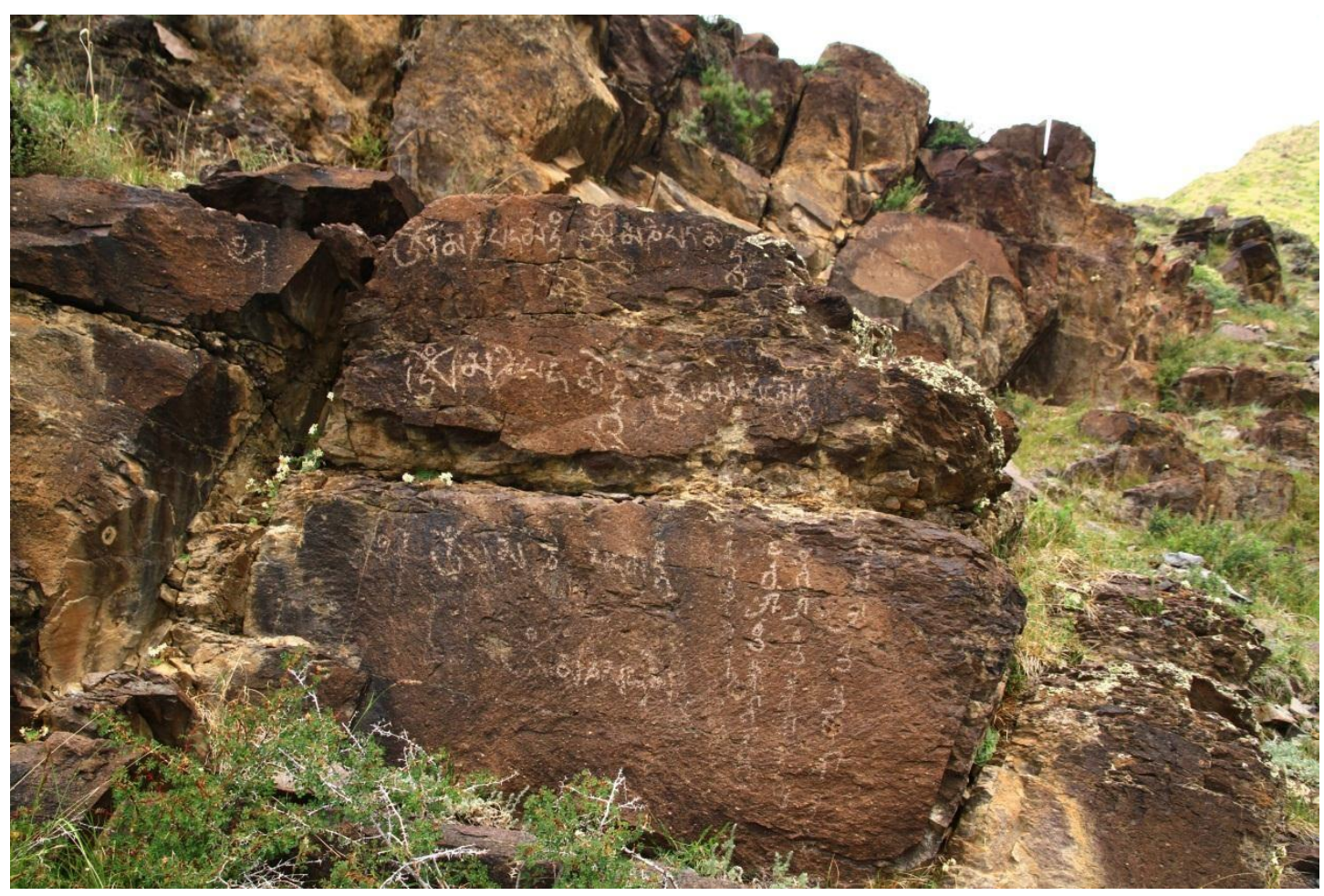

Рисунок 2. Надпись: «Ом-Мани-Падме-Хум» на тибетском и ойратском языках. Кайши

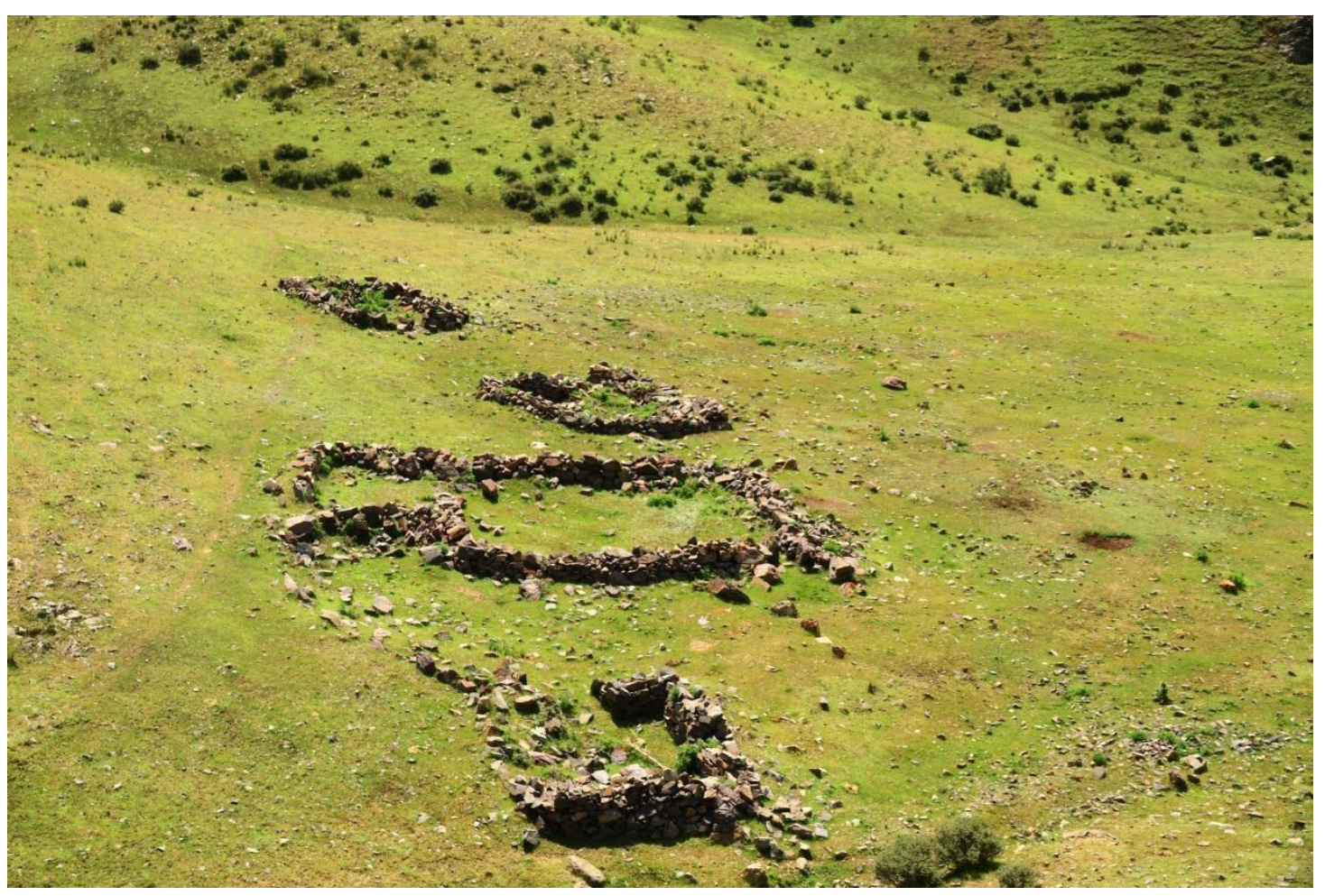

Рисунок 3. Руины построек (монастыря) у скал с надписями в Кайши 


\section{Әдебиеттер тізімі/ Список литературы}

1. Абрамов Н.А. Город Капал с его округом в 1862 г. // Записки Российского географического общества. - Т.1. 1867.

2 Абусеитова М.Х., Абылхожин Ж.Б., Кляшторный С.Г., Масанов Н.Э., Султанов Т.И., Хазанов А.М. История Казахстана и Центральной Азии: Учебное пособие. - Алматы: Издательство «Білім», 2001. - 620 c.

3. Археологическая карта Казахстана. Алма-Ата, 1960.

4. Бертольд В.В. Очерки истории Семиречья // Бартольд В.В. Собр. соч. в 9-ти томах. - Т.2. 4.1. - М., 1961.

5. Валиханов Ч.Ч. Дневник поездки на Иссык-Куль // Собрание сочинений в 5-ти томах. - Т.1. Алма-Ата, 1984.

6. Васильев Л.С. История религий Востока (религиозно-культурные традиции и общество). - М., 1983.

7. Волобуев В.И. Некоторые итоги реконструкции карты Джунгарии И. Рената // Известия НАН

РК. Сер. обществ. наук. - 1993. - №6.

8. Горячев А.А. Погребальные традиции поздней бронзы урочища Тамгалы в Чуилийских горах

// Вестник КазНУ им. Аль-Фараби. Серия историческая. - 2007. - №4(47). - С.132-138.

9. Деом Ж. Роль народов северных степей в распространении буддизма и театрального искусства из Центральной Азии в Китай во времена раннего средневековья (І в. до н.э. - Х в.н.) // Известия МНиВО РК, НАН РК. - 1999. - №1. - Серия общ. наук. - С. 133-156.

10. Древности Верненского уезда // Труды Четвертого Археологичекого съезда в России, бывшего в Казани с 31 июля по 18 августа 1877 года. - T.1. - Казань, 1884. Протоколы. C. XLIII, CVIII-CIX.

11. Ерофеева И.В. Памятники тибетского буддизма середины XVII- первой половины XVIII веков в Казахстане: новые исследования и находки // Научные чтения памяти Н.Э. Масанова. Сб. материалов научно-практической конференции. - Алматы, 2009.

12. Железняков Б.А. Алтарные наскальные композиции с оленями Жетысу (Кайши, Актерек) // История и археология Семиречья. - 2017. - № 5.

13. Жуковская Н.Л. Ламаизм и ранние формы религии. - М., 1977.

14. Зуев Ю.А. Китайские известия о Суябе // Известия АН КазССР. Серия истории, археологии и этнографиии. - 1960. - Вып.3(4). - С. 87-96.

15. Қазақстанның киелі орындарының географиясы. Табиғат, археология, этнография және діни сәулет өнері нысандарының тізілімі. - Алматы, 2017. - С.140-141.

16. Кастанье И.А. Древности Киргизской степи и Оренбургского края. - Алматы, 2007.

17. Кочетов А.Н. Буддизм. - М., 1983.

18. Кошеленко Г.А. О новейшей работе относительно судеб буддизма в Средней Азии // Вестник древней истории. - 2001. - №4. - С.200-210.

19. Княжецкая Е.А. Новые сведения об экспедиции И.М. Лихарева (1719-1720) // Страны и народы Востока. - Выпуск XXVI. - Кн.3. Средняя и Центральная Азия (география, этнография, история). - М., 1989.

20. Литвинский Б.А. Буддизм в Средней Азии (Проблемы изучения) // Вестник древней истории. 2001. - №4. С. 188-199.

21. Маргулан А.Х. О графическом наследии Ч.Ч. Валиханова // Валиханов Ч.Ч. Собр. соч. в 5-ти томах. - Т.5. - Алма-Ата, 1972.

22. Марстон А. Великая замкнутая страна. Прилож. к журналу «Естествознание и географрия». СПб, 1896. - Кн.5.

23. Марьяшев А.Н., Горячев А.А. Наскальные изображения Семиречья. - Алматы, 1998.

24. Моисеев В.А. Джунгарское ханство и казахи XVII-XVIII вВ. - Алма-Ата, «Ғылым», 1991. - 238 с.

25. Мифологический словарь. - М., 1991.

26. Никольский А.М. Путешествие на оз. Балхаш и Семиреченскую область // Записки Западно-

Сибирского отделения Русского географического общества. - Кн. VII. - Вып. І. - 1885.

27. Нурмухаммедов Н. Искусство Казахстана. - М., 1970. - С. 15-16, 35-36.

28. Позднеев А. Объяснения надписей и изображений Тамгалы-таса // Отд. оттиск из ЗВОРАО. Т.XI. - СПб., 1898. - С. 275-282.

29. Потапов С.А. Буддийские надписи и петроглифы долины р. Или... С. 3-4, 16-19.

30. Поярков, Ф.В.Из археологических экскурсий по Пичпескому уиезду и по берегам озера.

Памятная книжка Семириеченской области. - Верный, 1898. - С. 59-60.

31. Самашев 3. Наскальные изображения Казахстана // МНК «Кадырбаевские чтения - 2007». Актобе, 2007. - С. 165-186.

32. Семенов Тян-Шанский П.П. Мемуары. Т.ІІ. Путешествие в Тянь-Шань в 1856-1857 годах. - М., 1946. -256 с.

33. Ставиский Б.Я. Судьбы буддизма в Средней Азии (по данным археологии). - М.: «Восточная литература», 1998. - 216 с. 
34. Стобдан П. Образы Будды в Казахстане // Известия МОН РК, НАН РК. Сер. обществ наук. 2000. - №1. - С.182-185.

35. Токарев А. Религии в истории народов мира. - М.,1976.

36. Чеканский И.А. Развалины Кзыл-Кенеш в Каркаралинском округе Казахской АССР

(Исследование и библиография) // Записки Семипалатинского отдел. об-ва изучения Казахстана.

- 1929. - Вып. 18. - Т.1.

37. Фишер Г.В. Озеро Балхаш и течение р. Или от выс. Илийского до ея устьев // Записки Зап.

Сиб. отд. Русского географ. Общества. Кн.VI. - 1884.

38. Hermann L. Die Petroglyphen vom Usektal in Kasachstan. - Paris, 2011. - 72 p.

\section{References}

Abramov 1867 - Abramov, NA 1867, Gorod Kapal s ego okrugom v 1862 g, Zapiski rossiyskogo geograficheskogo obshestva, T.1. (Abramov, NA 1867, Kapal city with its district in 1862, Notes Of the Russian geographical community, T.1). (in Rus).

Abuseitova, Abylhozhin, Klyashtornyj 2001 - Abuseitova, MH, Abylhozhin, ZhB, Klyashtornyj, SG, Masanov, NEh, Sultanov, TI, Hazanov, AM 2001, Istoriya Kazahstana i Central'noj Azii. Uchebnoe posobie, «Bilim», 620 p. (Abuseitova, MH, Abylhozhin, ZhB, Klyashtornyj, SG, Masanov, NEh, Sultanov, TI, Hazanov, AM 2001, The History of Kazakhstan and Central Asia. Textbook, «Bilim», 620 p). (in Rus).

Arheologicheskaya karta 1960 - Arheologicheskaya karta Kazahstana 1960, Alma-Ata. (Archaeological map of Kazakhstan 1960, Alma-Ata). (in Rus).

Bertol'd 1961 - Bertol'd, VV 1961, Ocherki istorii Semirech'ya, Sobranie soch. v 9-ti tomah, T.2, Ch.1, Moscow. (Bertol'd, VV 1961, Essays on the history of Semirechye, Collection of works 9 toms, T.2, Ch.1, Moscow). (in Rus).

Valihanov 1984 - Valihanov, ChCh 1984, Dnevnik poezdki na Issyk-Kul', Sobr. soch. v 5-ti tomah, T.1, Alma-Ata. (Valihanov, ChCh 1984, Diary of a trip to Issyk-Kul, Collection of works 5 toms, T.1, Alma-Ata). (in Rus).

Vasil'ev 1983 - Vasil'ev, LS 1983, Istoriya religij Vostoka (religiozno-kul'turnye tradicii i obshchestvo), Moscow. (Vasil'ev, LS 1983, History of religions of the East (religious and cultural traditions and society), Moscow). (in Rus).

Volobuev 1993 - Volobuev, VI 1993, Nekotorye itogi rekonstrukcii karty Dzhungarii I. Renata, Izvestiya NAN RK. Ser. obshchestv. nauk. №6. (Volobuev, VI 1993, Some results of the reconstruction of the map of Dzungaria, Renata, Proceedings of NAS RK. Ser. societies'. sciences, №6). (in Rus).

Goryachev 2007 - Goryachev, AA 2007, Pogrebal'nye tradicii pozdnej bronzy urochishcha Tamgaly v CHuilijskih gorah, Vestnik KazNU im. Al'-Farabi. Seriya istoricheskaya, Almaty, №4(47), S.132138. (Goryachev, AA 2007, ., the Funerary tradition of late bronze Tamgaly in the Chu-ili moun-

tains, Bulletene of KazNU. Al-Farabi. A series of historical, Almaty, №4(47), S.132-138). (in Rus). Deom

1999 - Deom, Zh 1999, Rol' narodov severnyh stepej v rasprostranenii buddizma i teatral'nogo iskusstva iz Central'noj Azii v Kitaj vo vremena rannego srednevekov'ya (I v. do n.eh. - X v.n.), Izvestiya MN i VO RK, NAN RK Ser. obshch. nauk, № 1, S.133-156. (Deom, Zh 1999, the role of the peoples of the Northern steppes in the spread of Buddhism and dramatic art from Central Asia to China during the early medieval period (I century BC - C.X), Izvestiya MN and RK, NAS RK. Ser. societies'. sciences, № 1, S.133-156). (in Rus).

Drevnosti Vernenskogo 1884 - Drevnosti Vernenskogo uezda, Trudy CHetvertogo Arheologichekogo s"ezda v Rossii, byvshego v Kazani s 31 iyulya po 18 avgusta 1877 goda 1884, T.1, Kazan',. Protokoly. S. XLIII, CVIII - CIX. (Antiquities Verny County, Proceedings of the Fourth Archaeological Congress in Russia, which was held in Kazan from July 31 to August 18, 1877 1884, T.1, Kazan', Protokoly. P.XLIII, CVIII-CIX). (in Rus).

Erofeeva 2009 - Erofeeva, IV 2009, Pamyatniki tibetskogo buddizma serediny XVII- pervoj poloviny XVIII vekov v Kazahstane: novye issledovaniya i nahodki, Nauchnye chteniya pamyati N.EH. Masanova. Sb. materialov nauchno-prakticheskoj konferencii, Almaty. (Erofeeva, IV 2009, Monuments of Tibetan Buddhism of the middle of XVII-the first half of XVIII centuries in Kazakhstan: new researches and finds, Scientific readings of memory of $N$. Uh. Masanova. Sat. materials of scientific and practical conference, Almaty). (in Rus).

ZHeleznyakov 2017 - ZHeleznyakov, BA 2017, Altarnye naskal'nye kompozicii s olenyami ZHetysu (Kajshi, Akterek), Istoriya i arheologiya Semirech'ya, №5, Almaty, P.111-126. (ZHeleznyakov, BA 2017, Altarpiece rock compositions With deer, Zhetysu (kaishi, Akterek), History and archeology of Semirechye, №5, Almaty, P.111-126). (in Rus).

ZHukovskaya 1977 - ZHukovskaya, NL 1977, Lamaizm i rannie formy religii, Moscow. (ZHukovskaya, NL 1977, Lamaism and early forms of religion, Moscow). (in Rus). 
Zuev 1960 - Zuev, YuA 1960, Kitajskie izvestiya o Suyabe, Izvestiya AN Kaz.SSR. Ser. istorii, arheologii i ehtnografii, Vyp.3(4), P.87-96. (Zuev, YuA 1960, Chinese news about Suyab, Izvestia an KAZ.SSR. Ser. history, archeology and Ethnography, Vyp.3(4), P.87-96). (in Rus).

Geography of sacred places 2017 - Geography of sacred places in Kazakhstan 2017, Almaty. (Geography of sacred places in Kazakhstan 2017, Almaty). (in Rus).

Kastan'e 2007 - Kastan'e, IA 2007, Drevnosti Kirgizskoj stepi i Orenburgskogo kraya, Almaty. (Kastan'e, IA 2007, Antiquities of the Kirghiz steppe and the Orenburg region, Almaty). (in Rus).

Kochetov 1983 - Kochetov, AN 1983, Buddizm, Moscow. (Kochetov, AN 1983, Buddhism, Moscow). (in Rus).

Koshelenko 2001 - Koshelenko, GA 2001, O novejshej rabote otnositel'no sudeb buddizma v Srednej Azii, Vestnik Drevney Istorii, №4, P.200-210. (Koshelenko, GA 2001, on the latest work on the fate of Buddhism in Central Asia, Vestnik Drevney Istorii, №4, P.200-210). (in Rus).

Knyazheckaya 1989 - Knyazheckaya, EA 1989, Novye svedeniya ob ehkspedicii I.M. Lihareva (17191720), Strany i narody Vostoka. Vyp. XXVI. Kn. 3. Srednyaya i Central'naya Aziya (geografiya, ehtnografiya, istoriya), Moscow. (Knyazheckaya, EA 1989, New information about the expedition I. M. Likharev (1719-1720), Countries and peoples of the East. Vol. XXVI. kN. 3. Central and Central Asia (geography, Ethnography, history), Moscow). (in Rus).

Litvinskij 2001 - Litvinskij, BA 2001, Buddizm v Srednej Azii (Problemy izucheniya), Vestnik Drevney Istorii, №4, P.188-199. (Litvinskij, BA 2001, Buddhism in Central Asia (problems of study), Bulletene of Anticient historyi, №4, P.188-199). (in Rus).

Margulan 1972 - Margulan, AH 1972, About the graphic legacy of ChCh Valihanov, Valihanov, ChCh 1972, Sobr. soch. $v$ 5-ti tomah, T,5, Alma-Ata. (Margulan, AH 1972, About the graphic legacy of ChCh Valihanov, Valihanov, ChCh 1972, Sobr. soch. v 5-ti tomah, T,5, Alma-Ata). (in Rus).

Marston 1896 - Marston, A 1896, Velikaya zamknutaya strana. Prilozh. $k$ zhurnalu «Estestvoznanie $i$ geografiya», Kn.5. (Marston, A 1896, The Great closed country. Attachment. to the journal «Natural Science and geography», Kn.5). (in Rus).

Mar'yashev, Goryachev 1998 - Mar'yashev, AN, Goryachev, AA 1998, Naskal'nye izobrazheniya Semirech'ya, Almaty. (Mar'yashev, AN, Goryachev, AA 1998, Petroglyphs of Semirechye, Almaty). (in Rus).

Moiseev 1991 - Moiseev, VA 1991, Dzhungarskoe hanstvo i kazahi XVII-XVIII vv, «Gylym», Alma-Ata, 238 p. (Moiseev, VA 1991, Dzhungar khanate and Kazakhs of XVII-XVIII centuries, "Gylym», Alma-Ata, 238 p). (in Rus).

Mifologicheskij slovar 1991 - Mifologicheskij slovar 1991, Moscow. (Mythological dictionary 1991, Moscow). (in Rus).

Nikol'skij 1885 - Nikol'skij, AM 1885, Puteshestvie na oz. Balhash i Semirechenskuyu oblast', Notes of the West Sibirian buroe of Russian geografic obshchestva, Book VII, Issue I. (Nikol'skij, AM 1885, Puteshestvie na oz. Balhash i Semirechenskuyu oblast', Notes of the West Sibirian buroe of Russian geografic obshchestva, Book VII, Issue I). (in Rus).

Nurmuhammedov 1970 - Nurmuhammedov, N 1970, Iskusstvo Kazahstana, Moscow, P.15-16, 35-36. (Nurmuhammedov, N 1970, Art of Kazakhstan, Moscow, P.15-16, 35-36). (in Rus).

Pozdneev 1898 - Pozdneev, A 1898, Ob"yasneniya nadpisej i izobrazhenij Tamgaly-tasa, Otd. ottisk iz ZVORAO. T.XI, Saint Petersburg, S.275-282. (Pozdneev, A 1898, Explanations of inscriptions and images of Tamgaly-TAS, Otd. ottisk iz ZVORAO. T.XI, Saint Petersburg, P.275-282). (in Rus).

Potapov Nd - Potapov, SA 1898, Buddijskie nadpisi i petroglify doliny r. Ili..., P. 3-4, 16-19. (Potapov, SA 1898, Buddhist inscriptions and petroglyphs of the valley of the river, P. 3-4, 16-19). (in Rus).

Poyarkov 1898 - Poyarkov, FV 1898, Iz arheologicheskih ehkskursij po Pichpeskomu uiezdu $i$ po beregam ozera. Pamyatnaya knizhka Semiriechenskoj oblasti, Vernyj. (Poyarkov, FV 1898, Of the archaeological tours of Pipestone fesdu and along the banks of the lake. The memorable book of Semirechenskiy region, Vernyj). (in Rus).

Samashev 2007 - Samashev, Z 2007, Naskal'nye izobrazheniya Kazahstana, MNK «Kadyrbaevskie chteniya - 2007», Aktobe, P.165-186. (Samashev, Z 2007, Petroglyphs of Kazakhstan, MNK “ Kadyrbaeva readings - 2007», Aktobe, P.165-186). (in Rus).

Semenov Tyan-SHanskij 1946 - Semenov Tyan-SHanskij, PP 1946, Memuary. T. II. Puteshestvie v Tyan'-SHan' v 1856-1857 godah, Moscow, 256 p. (Semenov Tyan-SHanskij, PP 1946, Memoirs. T. II. Puteshestvie v Tyan'-SHan' v 1856-1857 godah, Moscow, 256 p). (in Rus).

Staviskij 1998 - Staviskij, BYa 1998, Sud'by buddizma v Srednej Azii (po dannym arheologii), «Vostochnaya literatura», Moscow, 216 p. (Staviskij, BYa 1998, The Fate of Buddhism in Central Asia (according to archeology), «Vostochnaya literatura», Moscow, 216 p). (in Rus).

Stobdan 2000 - Stobdan, P 2000, Obrazy Buddy v Kazahstane, Izvestiya MON RK, NAN RK. Ser. obshchestv nauk, №1, P.182-185. (Stobdan, P 2000, Obrazy Buddy v Kazahstane, Izvestiya MON RK, NAN RK. Ser. obshchestv nauk, №1, P.182-185). (in Rus).

Tokarev 1976 - Tokarev, A 1976, Religii v istorii narodov mira, Moscow. (Tokarev, A 1976, Religii v istorii narodov mira, Moscow). (in Rus). 
CHekanskij 1929 - CHekanskij, IA 1929, Razvaliny Kzyl-Kenesh v Karkaralinskom okruge Kazahskoj ASSR (Issledovanie i bibliografiya), Zapiski Semipalatinskogo otdel. ob-va izucheniya Kazahstana, T.1, Vyp.18. (CHekanskij, IA 1929, Razvaliny Kzyl-Kenesh v Karkaralinskom okruge Kazahskoj ASSR (Issledovanie i bibliografiya), Zapiski Semipalatinskogo otdel. ob-va izucheniya Kazahstana, T.1, Vyp.18). (in Rus).

Fisher 1884 - Fisher, GV 1884, Ozero Balhash i techenie r. Ili ot vys. Ilijskogo do eya ust'ev, Zapiski Zapadno-Sibirskogo otdelenia Russkogo geograf. Obshchestva, Kn.VI. (Fisher, GV 1884, City of Lake Balkhash and the river flow or from high, Notes Semipalatinsk Department. of the society of studying of Kazakhstan, Kn.VI.). (in Rus).

Hermann 2011 - Hermann, L 2011, Die Petroglyphen vom Usektal in Kasachstan, Paris, 72 r. (Hermann, L 2011, Die Petroglyphen vom Usektal in Kasachstan, Paris, 72 r). (in Fra). 